\title{
Dansk udenrigspolitik i tegningernes tegn
}

\section{Klaus Carsten Pedersen}

Det lykkedes den muslimske verden at ryste dansk diplomati og sætte sig på en stor del af Danmarks udenrigspolitiske dagsorden i efteråret og vinteren 2005-2006. Halvandet år senere føles det en smule uvirkeligt; men emnet optager over halvdelen af Danish Foreign Policy Yearbook 2007 fra DIIS

Nanna Hvidt og Hans Mouritzen (red.): Danish Foreign Policy Yearbook 2007. Danish Institute for International Studies. 2007. 197 s.

Denne halvofficielle udenrigspolitiske årbog udgives på engelsk for et internationalt publikum; men danskere må gerne læse med og hjælpes på gled af danske resuméer af bogens fire artikler. Artiklerne er skrevet af to diplomater og to forskere. De følges op af et dokumentationskapitel med udvalgte udenrigspolitiske taler: fire af statsministeren, seks af udenrigsministeren, en af miljøministeren og en af forsvarsministeren. Til slut følger fire sider med relevante statistikker, resultaterne af seks udvalgte meningsmålinger og en bibliografi.

Udenrigsministeriets direktør Ulrik Federspiel står som forfatter af den indledende artikel om den internationale situation og dansk udenrigspolitik i 2006. Han påpeger, at globaliseringen opstiller nye udfordringer og nye rammebetingelser for dansk udenrigspolitik. Politiske, økonomiske, kulturelle og miljømæssige begivenheder påvirkede Danmarks udenrigspolitiske dagsorden, og her udpeger han 'karikaturkrisen' som det altoverskyggende problem. Danmark befandt sig pludselig og uventet i centrum af en international krise, udsat for verbale, elektroniske, økonomiske og 


\section{LITTERATUR}

fysiske overgreb fra en lang række muslimske lande og fra muslimer i andre lande. Han sondrer mellem et mere eller mindre stødt, men fredeligt flertal og det larmende og voldelige mindretal, som medierne fokuserede på. Han er så taktfuld ikke at nævne indsatsen fra 'rejseholdet' af imamer fra Danmark. Han siger derimod, at støtten til Danmark fra især USA og EU bidrog afgørende til at stabilisere situationen, og at forholdet til regeringerne i de muslimske lande stort set var retableret $\mathrm{i}$ slutningen af 2006.

En anden stor opgave for Udenrigsministeriet var en følge af konflikten i Libanon. Der blev på meget kort tid blev organiseret evakuering til Danmark af ikke færre end 6.000 danskere, som opholdt sig på ferie eller forretning i Libanon, de fleste formodentlig af palæstinensisk herkomst og åbenbart ikke så vrede på Danmark, at de ikke gerne lod sig transportere hjem på ministeriets regning.

\section{Vennerne til hjælp}

Karikaturkrisen er også emnet for de to forskerbidrag til årbogen. Henrik Larsen, som er Jean Monnet professor ved Institut for Statskundskab på Københavns Universitet, undersøger Danmarks bestræbelser på at involvere EU og USA i løsningen af krisen. Han giver til indledning at glimrende rids af hele forløbet, som vil være en god hjælp for eventuelle fremtidige læsere, der ikke selv har oplevet krisen. Han påpeger, at de modstående synspunkter i den offentlige diskussion kommer til at stå mellem 'respekt for ytringsfrihed' og 'respekt for religion'.

Reaktionen på krisen i EU og USA var indledningsvis tøvende, kritisk og - især fra amerikansk side irriteret over at blive stillet over for et problem, man ikke havde bedt om. Men efter angrebene på ambassaderne var der hurtigt både politisk, diplomatisk og praktisk støtte fra såvel EU som USA, hvor man ganske vist fortsat fandt tegningerne usmagelige eller i det mindste unødvendige, men samtidig fandt voldsepisoderne i en række muslimske byer og særlig ambassadeangrebene og tabene af menneskeliv fuldkommen uacceptable. Hele denne udvikling er beskrevet grundigt og nuanceret.

Hovedkonklusionen på de 31 tilfredsstillende sider er, at forløbet ikke har medført nogen ændring i den officielle forståelse af henholdsvis EU's og USA's rolle i dansk udenrigspolitik, men at vægten på EU's betydning nok er øget. Trods krisens lektion i diplomatiets kunst i en globaliseret verden betragtes EU og USA fortsat som fundamentale allierede i forsvaret af danske interesser.

\section{Det var (kun) vores skyld}

Helle Rytkønen er Ph.d. og underviser på Stanford University i Califor- 
nien. Hun analyserer forløbet af karikaturkontroversen i henholdsvis USA og Europa med særlig vægt på Danmark. Hun påpeger mange forskelle i fx pressedækningen og, at der generelt i USA ses med større velvilje på (alle mulige former for) religion end i det overvejende sekulære Europa.

Hun beskriver USA som betydelig mere tolerant og rummeligt end Europa og især Danmark i forhold til muslimske indvandrere. Hun er, for at sige det kort, uforbeholdent kritisk over for Danmarks og danskernes håndtering af den bølge af indvandring, der har fundet sted i løbet af blot en generation.

Det forekommer i den forbindelse påfaldende, at der i hendes referenceliste ikke optræder en eneste af den lange række analyser fra Rockwool Fondens Forskningsenhed, analyser af indvandringens karakter og omfang, integrationens problemer og succeser, forholdene i sammenlignelige lande etc.

Hun citerer til gengæld bl.a. amerikanske muslimer, hvis kendskab til europæiske forhold synes yderst begrænset. Hun nævner de danske imamers 'rejsehold', men ikke at der i det materiale med hvilket de søgte at opildne til aktion mod Danmark var materiale, som ikke var dansk, og materiale, som ikke havde været offentliggjort.

Hun nævner, at ytringsfriheden i USA inkluderer friheden til ikke at fornærme folk (det lyder smart, men piller i nogen grad glansen af begrebet). Det har i øvrigt også ofte været fremført i Danmark, dog mest i den mere meningsfulde version, der siger, at ytringsfriheden ikke er en pligt til at ytre sig fornærmende at man kan overveje at lade være, hvis lødige argumenter skulle tale derfor. Hun hæfter sig ikke ved, at der i hele forløbet i Danmark ikke blev krummet et hår på nogens hoved, eller at den langstrakte debat $i$ karikaturernes kølvand på mange måder har vist sig konstruktiv.

Hun konkluderer nærmest, at hovedproblemet er, at 'Vesten', USA og Europa, bygger barrierer op, hvor man burde bygge broer, fordi man vælger at definere islam og muslimernes kultur som tilbagestående og uforligelig med et moderne demokratisk samfund, og at Vesten svigter de værdier, som Vesten hævder at forsvare.

Man kan spørge, om hun ikke kommer til at nedvurdere muslimerne ved at lægge alt ansvar og al skyld på Vesten. Hendes artikel ligner mere et partsindlæg i en politisk debat end en akademisk undersøgelse; men læsere, der hænger på til enden, bliver dog belønnet med hendes fine analyse af en af de tolv tegninger, den der ikke fremstiller profeten Muhammed, men drengen Muhammed ved tavlen i 7. klasse i Valby.

Karikaturkrisen var en chokerende oplevelse for udenrigsministeriet, som netop havde lagt mange kræf- 


\section{LITTERATUR}

ter i 'Det Arabiske Initiativ', og enkelte firmaer blev ramt på deres omsætning; men her halvandet år senere kan man konstatere, at "den værste krise for dansk udenrigspolitik siden Anden Verdenskrig" ikke satte sig synlige spor i dansk økonomi, og at forholdet til selv de mest aktive kritikere af Danmark er normaliseret.

\section{Sikkerhedsrådet}

Den fjerde artikel er meget driftsikre ambassadør Ellen Margrethe Løjs gennemgang af de væsentligste af Sikkerhedsrådets sager i de to år, hun sad der som Danmarks repræsentant. Hun nævner Anti-terrorismekomitéen, hvis formand hun var, og hun gennemgår Liberia-krisen og udviklingen i Sudan og Darfur; men hun giver også en god beskrivelse af Sikkerhedsrådets sammensætning, arbejdsmåde og betydning mere generelt.

Årbogen anbefales til læsning. 